\title{
Development of a new Aerosol Barrier Mask for mitigation of spread of SARS-CoV-2 and other infectious pathogens
}

\author{
Karam Abi Karam ${ }^{1}$, Piyush Hota ${ }^{1,3}$, S. Jimena Mora ${ }^{1}$, Amelia Lowell ${ }^{2}$, Kelly McKay ${ }^{2}$ \\ Xiaojun Xian ${ }^{1}$, Bhavesh Patel ${ }^{* 2}$, Erica Forzani*1,3 \\ Corresponding authors: patel.bhavesh@mayo.edu; eforzani@asu.edu \\ ${ }^{1}$ Center for Bioelectronics and Biosensors, Biodesign Institute, Arizona State University, \\ Tempe, 85281, Arizona, USA \\ ${ }^{2}$ Mayo Clinic, Phoenix, 85054, Arizona, USA \\ ${ }^{3}$ School of Engineering for Matter, Transport, and Energy, Arizona State University, Tempe, \\ 85281, Arizona, USA
}

\begin{abstract}
The COVID-19 pandemic has caused huge impact on public health and significantly changed our lifestyle. This is due to the fast airborne oro-nasal transmission of SARSCoV-2 from the infected individuals. The generation of liquid aerosolized particles occurs when the COVID-19 patients speak, sing, cough, sneeze, or simply breathe. We have developed a novel aerosol barrier mask (ABM) to mitigate the spread of SARSCoV-2 and other infectious pathogens. This Aerosol Barrier Mask is designed for preventing SARS-CoV-2 transmission while transporting patients within hospital facilities. This mask can constrain aerosol and droplet particles and trap them in a biofilter, while the patient is normally breathing and administrated with medical oxygen. The system can be characterized as an oxygen delivery and mitigation mask which has no unfiltered exhaled air dispersion. The mask helps to prevent the spread of SARS-CoV-2, and potentially other infectious respiratory pathogens and protects everyone in general, especially healthcare professionals.
\end{abstract}

Keywords: COVID-19, SARS-CoV-2, Transmission, Mitigation, Aerosols, Droplets, Mask, Pandemic, Healthcare workers

\section{Introduction}

As of February $5^{\text {th }}, 2021$, the Word Health Organization reported more than 104 million confirmed cases of COVID-19, including more than 2.2 million deaths globally. ${ }^{1}$ These substantial numbers are the consequence of the transmission of the Severe Acute Respiratory Syndrome Coronavirus 2 (SARS-CoV-2). It is transmitted by droplets and aerosols generated by infected individuals during their exhalation. ${ }^{2}$ An individual infected with COVID-19, would potentially infect others by natural human actions such as breathing, speaking, coughing, sneezing, etc. ${ }^{3,4,5}$ Healthcare professionals are the most vulnerable population since they are caring for infected patients. ${ }^{6,7}$ Considering the severity of the pandemic, it is important to reduce and control the spread of the

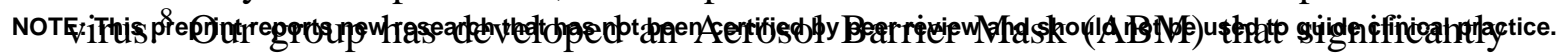


medRxiv preprint doi: https://doi.org/10.1101/2021.02.11.21251593; this version posted February $12,2021$. The copyright holder for this preprint (which was not certified by peer review) is the author/funder, who has granted medRxiv a license to display the preprint in

It is made available under a CC-BY-NC-ND 4.0 International license .

reduces the airborne transmission of virus-containing respiratory droplets from inpatients during their transportation in hospital facilities. The design of the mask also includes an oxygen fitting allowing its administration to the patient. ABM is considered an innovative and efficient system designed particularly to protect healthcare professionals. This Aerosol Barrier Mask is proved to be very effective in mitigating the spread of SARS-CoV-2 in hospital settings.

\section{Materials and Methods}

The three subjects involved in the test study participated voluntarily and signed informed consents.

The tests were carried out by Arizona State University (ASU) researchers at Mayo Simulation Centers at Phoenix, Arizona in April 2021. The study was approved by the Institutional Review Board of Arizona State University (IRB reference protocols \# STUDY00006547).

\subsection{Mask Design and Components}

The mask was redesigned and retrofit using an existing single-use mask from the Breezing Pro ${ }^{\mathrm{TM}}$ metabolic tracker. ${ }^{9}$ The mask is equipped with two connectors as observed in Fig. 1A and B. The central coupler is an outlet port that connects to the main flow Anti-Bacterial/Viral Filter, which further connects to an appropriately designed fan to suction out the aerosols generated from the wearer (flow rate: 3.6-4.3 CFM at zero static pressure). The second connector is an oxygen port, sealed with a medical-grade adhesive, allowing the administration of medical oxygen. The mask has a comfortable and adjustable strap to hold it in position on the patient's head. The fan is powered by a $5 \mathrm{~V}$ portable and a rechargeable battery pack, and it can be reused for multiple times.

\subsection{Particles Count}

To quantify the number of aerosols, a commercial laser particle counter, Dylos DC1100 (Dylos Corporation, CA) was used. This air quality monitor detects particles between 0.5 and 2.5 microns. The monitors were installed at three distinct locations away from the subject $-1.3 \mathrm{ft}$ towards the left, $2 \mathrm{ft}$ towards the right, and $13 \mathrm{ft}$ longitudinally away (data not shown). The aerosols generated by coughing and sneezing simulations were accomplished by ten puffs with a sprayer at the subject's mouth level. The resulting concentration of aerosol particulates were studied with and without the ABM system.

\subsection{Comparison of Inhaled Carbon Dioxide Measurement}

An infrared $\mathrm{CO}_{2}$ VacuMed analyzer, silver edition Model 17630, was used to measure the concentration of the corresponding gas accumulated by breath using the ABM. The assessments of $\mathrm{CO}_{2}$ levels were conducted in 5 different conditions:

i. $\quad$ ABM with filter, 15 LPM of oxygen, and fan turned OFF

ii. $\mathrm{ABM}$ with filter, $15 \mathrm{LPM}$ of oxygen, and fan turned $\mathrm{ON}$

iii. $\quad A B M$ with filter, fan turned $\mathrm{ON}$, with no oxygen tank

iv. ABM with filter, fan turned OFF, with no oxygen tank

v. An N-95 mask, with ambient air for comparison 
medRxiv preprint doi: https://doi.org/10.1101/2021.02.11.21251593; this version posted February $12,2021$. The copyright holder for this preprint (which was not certified by peer review) is the author/funder, who has granted medRxiv a license to display the preprint in

It is made available under a CC-BY-NC-ND 4.0 International license .

It is important to note, with the absence of oxygen supply, ambient air was available to the user through the one-way inhalation valve on the mask. The data was collected using a Bluetooth Data Acquisition Module - BTH-1208LS manufactured by Measurement Computing. Measurements were taken every 5 minutes with a 1-minute interval for a total time of 30 minutes. The $\mathrm{CO}_{2}$ inhalation average and standard deviation were calculated using the acquired data set.

\section{Results}

The mask is specially designed to provide safe movement/transportation of COVID-19 patients who generate contaminated aerosols via coughing, sneezing, or by use of their vocal cords. In addition, the system can be used when the patient is inside an imaging system such as a CT scanner without contaminating the surroundings. The ABM is a light and comfortable single-patient use mask $(\leq 100 \mathrm{~g})$ that is easy to place on the person's face.

A

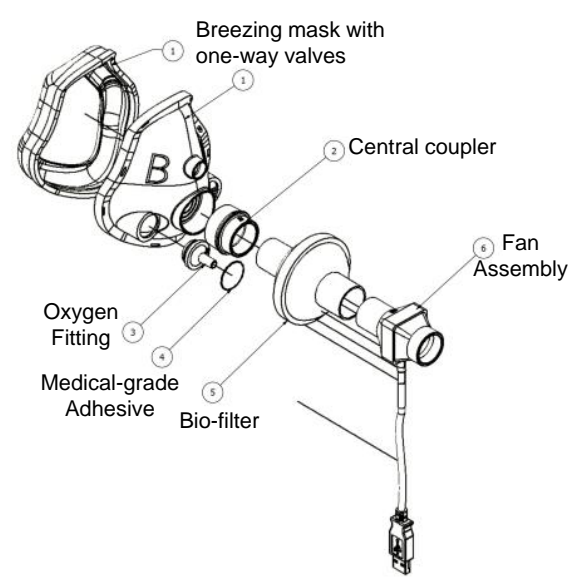

C

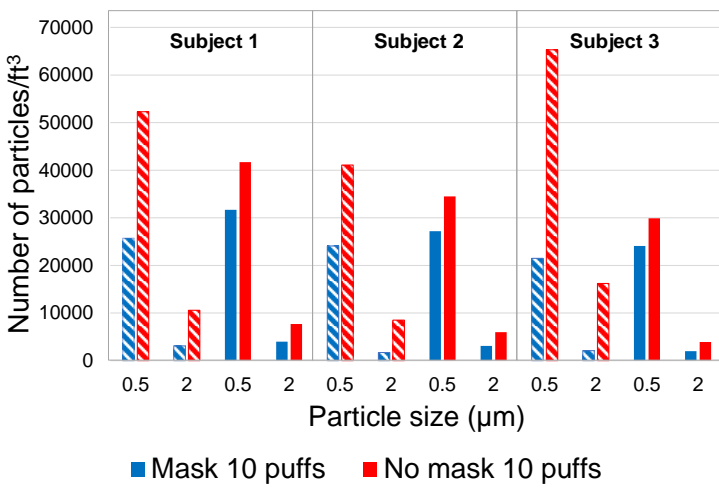

B

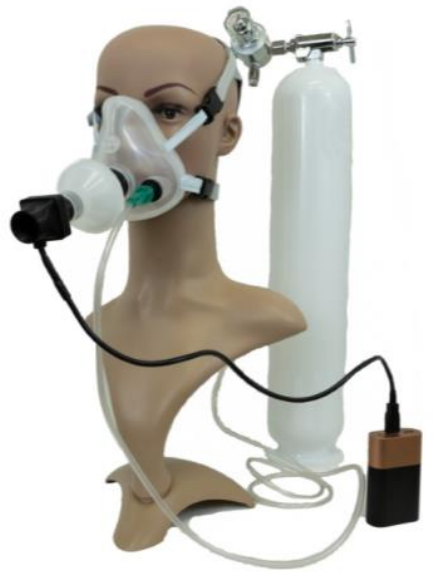

D

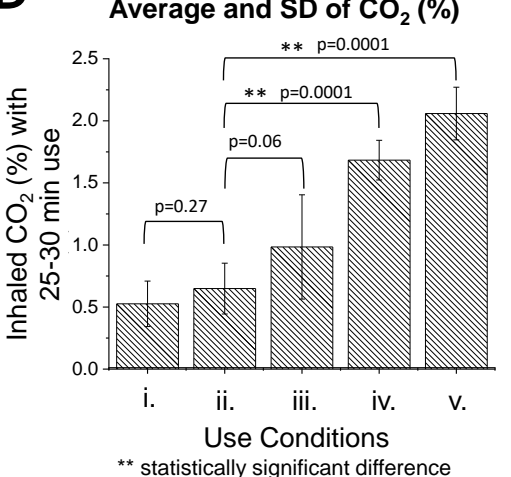

Figure 1. A, B) Mask designed for a safer transportation of COVID-19 patients in healthcare facilities. The ABM has an outlet port with a bio-filter connected to a fan for negative pressure and a port for oxygenation. C) Plots of maximum number of aerosol particles/feet ${ }^{3} v s$ particle size measured by simulated coughing and sneezing at different distances from a subject. (hatched columns correspond to $1.3 \mathrm{ft}$ and solid to $2 \mathrm{ft}$ ) with and without the ABM (blue and red, respectively). The average of the maximum number of particles/feet ${ }^{3}$ for the $0.5 \mu \mathrm{m}$ and 2 $\mu \mathrm{m}$ particle size corresponding to the baseline is represented by the dashed and dash-dotted line respectively. D) The graph shows the inhaled $\mathrm{CO}_{2}$ levels of the $\mathrm{ABM}$ system under different conditions - i. $\mathrm{O}_{2}$ with Fan OFF, ii. $\mathrm{O}_{2}$ with Fan $\mathrm{ON}$, iii. ambient air via an emergency inhalation valve with fan ON, iv. ambient air via an emergency inhalation valve with fan OFF, v. $\mathrm{CO}_{2}$ concentration with a reference $\mathrm{N} 95$ mask in ambient air. 
medRxiv preprint doi: https://doi.org/10.1101/2021.02.11.21251593; this version posted February $12,2021$. The copyright holder for this preprint (which was not certified by peer review) is the author/funder, who has granted medRxiv a license to display the preprint in

It is made available under a CC-BY-NC-ND 4.0 International license .

Figure 1C shows the plot of the maximum number of aerosol particles per cubic feet measured during the experiments (typically at a time lapse of 20 minutes) for particle sizes corresponding to $0.5 \mu \mathrm{m}$ and $2 \mu \mathrm{m}$ at different distances from 3 subjects with and without the ABM system. The assembly of mask, filter, and fan enabled to mitigate almost $100 \%$ of the dispersed aerosol particles effectively. On the other side, the generation of aerosols was detected specifically for short distances. It is important to note that the ventilation of the room has a big influence on aerosol detection in short distances. For example, in this case-study, more aerosols were detected at 2 feet distance rather than 1.3 feet.

Fig. 1D shows the inhaled carbon-dioxide levels using the ABM for different conditions as discussed in section 2.3. It is evident that the fully functional aerosol mitigation mask shows better breathing conditions than an N95 mask supplied with ambient air. Even at other conditions, i.e. if one of the components of the system fails (fan or oxygen), the results assured relatively safer conditions for the wearer. Importantly, the characteristics of the fan are relevant and must sustain a flow compatible with the subject's breathing rate (e.g., breathing peak flow, frequency, end-tidal volume, and average exhalation rate) in addition to the oxygen therapy's flow which is dependent on the type of oxygen delivery.

\section{Conclusions}

An Aerosol Barrier Mask has been developed to prevent the spread of SARS-CoV-2 while transporting infected in-patients through hallways, elevators, and other places within hospital facilities. It has been shown that the ABM can mitigate close to a $100 \%$ of the aerosols and droplets generated by the wearer, which helps protect the individuals in proximal contact with the infected patients. Moreover, there is no carbon-dioxide accumulation inside the mask, outside the normal breathing range when the patient is administrated with oxygen. The ABM is a new alternative to help the mitigation of COVID-19.

\section{Conflict of interest}

All authors, except XX and EF declare no conflict of interest. XX and EF are associated with TF Health Co. (d.b.a. Breezing Co.).

\section{Acknowledgments}

The authors acknowledge SEMTE, ASU, Mayo Clinic, Biodesign Institute, and NIH R03 funding from NIBIB (EB027336-02)

\section{Reference}

1 W. H. Organization, "WHO Coronavirus Disease" [Online]. Available: https://covid19.who.int/.

${ }^{2}$ Centers for Disease Control and Prevention, "Scientific Brief: SARS-CoV-2 and Potential Airborne Transmission" [Online]. Available: https://www.cdc.gov/coronavirus/2019ncov/more/scientific-brief-sars-cov-2.html. [Accessed 0202 2021] 
medRxiv preprint doi: https://doi.org/10.1101/2021.02.11.21251593; this version posted February $12,2021$. The copyright holder for this preprint (which was not certified by peer review) is the author/funder, who has granted medRxiv a license to display the preprint in It is made available under a CC-BY-NC-ND 4.0 International license.

${ }^{3}$ K. Nissen, J. Krambrich, D. Akaberi, T. Hoffman, J. Ling, Å. Lundkvist, L. Svensson and E. Salaneck, "Long-distance airborne dispersal of SARS-CoV-2 in COVID-19 wards" Scientific Reports, vol. 10, no. 1, pp. 1-9, 2020.

${ }^{4}$ Z. Renyi, Y. Li, A. L. Zhang, Y. Wang and M. J. Molina, "Identifying airborne transmission as the dominant route for the spread of COVID-19" Proceedings of the National Academy of Sciences, vol. 117, no. 26, pp. 14857-14863, 2020.

${ }^{5}$ J. Mahesh, H. Perera, B. Gunawardana and J. Manatunge, "Transmission of COVID-19 virus by droplets and aerosols: A critical review on the unresolved dichotomy" Environmental research, p. 109819, 2020.

${ }^{6}$ L. Nguyen, D. Drew, M. Graham, et al. "Risk of COVID-19 among front-line health-care workers and the general community: a prospective cohort study" Lancet Public Health, vol. 5, p. $475-83,2020$.

7 J. Bielicki, X. Duval, N. Gobat, H. Goossens, M. Koopmans, E. Tacconelli, S. Van Der Werf. "Monitoring approaches for health-care workers during the COVID-19 pandemic" Lancet Infect Dis, vol. 20, p. 261-67, 2020.

${ }^{8}$ D. Leasa, P. Cameron, K. Honarmand, T. Mele, K.Bosma. "Knowledge translation tools to guide care of non-intubated patients with acute respiratory illness during the COVID-19 Pandemic" Crit Care, 25:22, 2021.

${ }^{9}$ TF Health Corporation, "Breezing Pro," [Online]. Available: https://breezing.com/product/. 
A

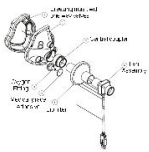

c

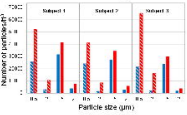

- Mases: 10 purfe = Na mast 10 purfe
B

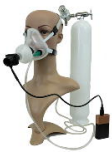

D hverage and $\mathrm{SD}$ or $\mathrm{CO},\langle\mathrm{s}$

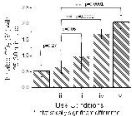

